\title{
Licensed as Wholesale Drug Distributor or Third Party Logistics Provider
}

National Cancer Institute

\section{Source}

National Cancer Institute. Licensed as Wholesale Drug Distributor or Third Party Logistics Provider. NCI Thesaurus. Code C118779.

An indication that an entity has been an issued a license to function as a wholesale drug distributor or as a third party logistics provider within a state's territory. 